\title{
Effects of Companies' Initiatives to Reduce Early Retirement Among Older Workers
}

I Tove Midtsundstad

Researcher, Fafo Institute for Labour and Social Research, Norway ${ }^{1}$

I Åsmund Hermansen

Researcher, Fafo Institute for Labour and Social Research, Norway

I Roy A. Nielsen

Researcher, Fafo Institute for Labour and Social Research, Norway

\begin{abstract}
Although active ageing policy and practice vary between countries, we believe that knowledge about the effects of Norwegian companies' initiatives to delay early retirement is of interest for all countries striving to increase the employment rates of older workers. Since the agreement on a more inclusive working life (IW agreement) was signed in 200I, the Norwegian government and social partners have encouraged companies to develop a more senior-friendly policy and implement special measures to retain older workers. In this article, we evaluate the effects of such measures. Our research question is, have preventive measures offered by companies to employees aged 62 years and older contributed to reduced rates of early retirement? We use a 'difference-in-differences' approach and examine whether measures at the company level to counteract early retirement actually affect older employees' retirement decisions, controlling for different individual and enterprise factors. This is done by comparing changes and differences in the individual likelihood of early retirement on the contractual pension (AFP scheme) and disability pension in the period 2002-2007 among employees 62 years of age in businesses with and without the corresponding preventive measures/instruments. The analyses show that the likelihood that a 62-year-old worker will retire on the AFP scheme has increased from 2002 to 2007. This applies equally to 62-year-old employees in enterprises that have enacted special measures to retain older workers as well as 62-year-olds in enterprises that have not enacted any such measures. On the other hand, the likelihood that a 62-year-old worker will retire because of disability decreased from 2002 to 2007, among employees in both the intervention enterprises and the control enterprises. However, when controlling for other relevant characteristics of individuals and enterprises, the analysis indicates that the measures as such have had no effect on the likelihood of 62-year-olds retiring.
\end{abstract}

\section{KEY WORDS}

Difference-in-difference / disability pension / effect evaluation / early retirement / measures to retain older worker / older employees / registry data / senior-policy measures / survey data

\footnotetext{
${ }^{1}$ Tove Midtsundstad, Researcher, Fafo Institute for Labour and Social Research, Norway.

E-mail: tove.midtsundstad@fafo.no
} 


\section{Background and research question}

nternationally, people have long been concerned with senior policy as a way to tackle the challenge of an ageing population, and several studies of so-called active ageing policy and practice have been published, under the auspices of the EU (Taylor 2006; Walker 1997, 1999), the OECD (2006), and the European Trade Union Institute (ETUI; Jepsen et al. 2003). In this literature, the focus has generally been on employers' attitudes, age discrimination, and the need for attitude campaigns and socalled lifelong learning. One of the exceptions in this situation is Finland, where the researchers have primarily been concerned with working capacity (the Work Ability Index) and working environment (see, for example, Ilmarinen \& Louhevaara 1999; Sterdyniak 2007). On the other hand, special senior-policy initiatives instigated by enterprises, of the kind we find in Norway, which include reduced working hours with and without wage compensation, bonuses and increased wages, longer holidays or more days off, etc. (Midtsundstad 2007; Midtsundstad \& Bogen 2011b), are not widespread in other countries (Taylor 2006), although focus on economic incentives and reduced working hours as effective means to postpone retirement are widespread in the international literature (e.g., Delsen \& Reday-Mulvey 1996; OECD 2006; Taylor 2006; Vickerstaff et al. 2009). However, there is little international research concerning the effects of initiatives of this kind. The main aim of this article is to examine whether these senior-policy initiatives, offered by Norwegian companies, have had the desired effect on retirement behavior.

The Tripartite Agreement on an Inclusive Working life (the IW agreement) is, together with the ongoing pension reform, the Norwegian strategy to tackle the demographic shift that endangers future labor supply and the sustainability of national pension systems. Since the parties in the Norwegian labor market and the Norwegian government signed the agreement in 2001, different workplace initiatives have been in focus to reduce early retirement. The employers are increasingly aware of the need for HR policies that take account of older workers: in 2010, half of all Norwegian employees were working in enterprises covered by the IW agreement, and nine out of ten IW enterprises had implemented senior or life-stage policies (Midtsundstad 2007; Midtsundstad \& Bogen 2011b).

The actual age of retirement in Norway has in fact increased since 2001 (Haga 2010). However, whether the reduction in the rate of early retirement is a direct effect of the measures targeting seniors in the enterprises following from the IW agreement remains unclear. A quantitative study conducted by Bowitz (2003) nevertheless indicates that these policies are effective, but produce different outcomes for men and women. However, his conclusion is based exclusively on data for employed older people (55-65 years), and the study investigates retirement preferences, not actual retirement behavior. ${ }^{1}$ On the other hand, a study of retirement on contractual pension (the AFP scheme) among a representative sample of employees and retirees in the public sector shows that facilitation and adaptation of job content and working hours have no effect on retirement behavior (Midtsundstad 2005b). Qualitative studies also indicate that the measures in use, bonuses and offers of reduced working hours, have little or no effect on retirement behavior or job availability among older people (see, e.g., Becken 2011; Hilsen \& Salomon 2010; Midtsundstad 2009; Midtsundstad \& Bogen 2011b; Midtsundstad et al. 2012). 
In addition to limitations imposed by the material or the methodology, a possible explanation for these varying, lacking, or conditional effects of policies for seniors could be that the applied initiatives fail to reach their target group or that the effects vary between sectors, industries, and professions. Thus, further analyses of the effects of the measures enacted by the enterprises are needed, and this motivates this article. The main research question of this article is, Do policies targeting workers aged above 62 years reduce the individual likelihood of retiring on the AFP scheme or on disability at age 62 ?

We are using a "difference-in-differences" approach, where we compare the change in individual likelihood of early retirement for people aged 62 years in enterprises with and without special policies for seniors, during a period before the enactment of such initiatives (2001-2004) and a period after the introduction of such policies (2005-2007). The data comprise survey information on special senior-policy initiatives instigated by enterprises and registry information on retirement behavior and background characteristics of all employees who turned 62 during the period from 2001 through 2007 and who were working in a representative sample of 713 enterprises employing ten people or more.

Before presenting and discussing the findings, we will define the concepts of workoriented policies for seniors and special measures for seniors. We will also provide a brief overview of previous research in this field, as well as a presentation of our data and methodology.

\section{Theoretical basis and previous research}

The explanations for early retirement are manifold and complex. Economic analyses primarily place the emphasis on the design of the pension system (pull factors): how payment levels and corresponding tax levels, age restrictions, and selection criteria serve to pull employees out of working life early (Hernæs et al. 2002). Other research has shown that early retirement is due to conditions in the workplace (push factors) as much as in the domestic sphere or the family (jump factors) (e.g. Hallberg 2007; Hauge \& Årethun 2008; Larsen 2005; Lindquist \& Wadensjö 2009; Midtsundstad 2006; Philipson \& Smith 2005; Steinum et al. 2007). In addition, a number of studies show that individual circumstances such as gender, age, education level, professional background and career, health, and finances also play an important part concerning the decision to retire, although their influences are different for different professional and educational groups (Hallberg 2007; Hauge \& Årethun 2008; Midtsundstad 2002, $2005 \mathrm{a}, 2005 \mathrm{~b}$ ). Well-educated people retire later than less educated people. And whereas early retirement is related to health problems, heavy professional burdens, and long careers among blue-collar workers and low-ranking white-collar workers, these factors are less important among high-ranking white-collar workers and managers. For the latter groups, it is apparent that loss of interest and motivation regarding work can be just as important (Midtsundstad 2002, 2005a).

In other words, research on early retirement shows that workplace conditions also affect the decision to retire early, in addition to the design of pension systems, individual resources, and factors related to the domestic sphere or the family. This has provided the background for the efforts to implement policies for seniors at the workplace. 
However, there is little systematic knowledge of whether and to what extent active measures enacted by enterprises for their older workers actually have an effect on older workers' retirement behavior. Available studies include trials that identify the effect of individual measures on the ability to work, job satisfaction, skills, job motivation, and coping (e.g., Hilsen \& Salomon 2010; Hilsen \& Steinum 2006; Ilmarinen \& Louhevaara 1999; Solem 2001). Studies under the auspices of the FinnAge programme, for example, claim to demonstrate that facilitation of a healthy lifestyle is essential to prevent a premature reduction in the capacity to work and function among older employees. Similarly, a number of Finnish studies show that physical exercise arranged at the workplace, including various occupational therapy measures, have positive effects on the ability of health personnel to work (Parkatti et al. 1999; Pohjonen 2001). Other studies provide more detail to this conclusion, pointing out that this will only apply when the interventions are targeted and succeed in reaching those who would otherwise not be physically active (see overview in NOU 2010: 13).

Analyses of the causes of early retirement on the AFP scheme in Norway among public and private sector employees, respectively, nevertheless indicate that according to the older workers themselves, reduction and adaptation of workloads, such as adaptation of job content and pace, have had an effect on decisions regarding retirement (Midtsundstad 2002, 2005b). Hurd and McGarry (1993) have also shown that the opportunity to move into a less demanding job (lighter workload) for the same employer tends to increase the likelihood of a desire to delay retirement. A study by Panis et al. (2002) came to the same conclusion. Some Finnish studies have also shown that adaptation of shift-work schedules and various types of more convenient rota schedules have a positive effect on older workers' health and ability to work (Kandolin 1999).

Several case studies also suggest that development of competence and skills throughout the entire working career may impact on whether the individual employee will be able to fulfill his or her job requirements, and that this will be particularly important in workplaces subject to continuous changes in job and skills requirements (Jørgensen et al. 2005; Ilmarinen 2003). However, only very few studies have actually demonstrated that those who receive continuous training provided by employers throughout their working careers in fact retire later than those who have had no such opportunity, ceteris paribus (Mayhew \& Rijkers 2004; Philipson \& Smith 2005). A Swedish longitudinal study of the effects of lifelong learning also fails to document that such interventions have an effect on retirement behavior (de Luna et al. 2008).

In terms of policies for seniors and measures aiming to reduce the rate of early retirement, the opportunities for flexible working hours, partial retirement, and reduced working hours with or without wage compensation have over time been regarded as suitable instruments for increasing the supply of labor among the elderly (see, e.g., Delsen \& Reday-Mulvey 1996; OECD 2006; Taylor 2006; Vickerstaff et al. 2009). In spite of the widespread interest in and focus on such schemes on the part of politicians, employers, and employees alike (Midtsundstad 2005a, 2006, 2009b; Mykletun et al. 2000; Stortingsmelding nr. 6 (2006-2007); Torgén et al. 2001), the documented effects remain inconclusive (Philipson \& Smith 2005).

The trials of six-hour working days in the Tine dairy concern have documented positive effects on individual job satisfaction and willingness to continue working with reduced working hours (Olberg 2006). Visser (2002), in his studies of the relationship between access to part-time work and employment rates in EU countries such as the 
Netherlands, found that access to part-time work increased the employment rate of women significantly. Other studies suggest a similar effect on the job availability of young people, most likely because access to part-time work allows for a combination of work and studies (Ryan et al. 1991). Wadensjö (2006), who evaluated the Swedish public scheme for subsidized partial retirement (1976 to 2000), also concluded that the scheme had a positive effect on the supply of labor (number of hours worked), especially among women, but that the scheme needed to appear as financially attractive in order to produce any such positive effect. In addition to increasing the supply of labor by way of delayed retirement, such schemes are also assumed to have health benefits, thereby helping people maintain their ability to work and thus remain in the job for some additional years.

Other studies, on the other hand, indicate the possibility that the opportunity for flexible retirement, especially in subsidized forms, would induce a larger number of those who otherwise would have continued working full-time to reduce their working hours, rather than encouraging a large proportion of those who otherwise would have retired to continue working (Becken 2011; Hilsen \& Salomon 2010; Midtsundstad \& Bogen 2011a, 2011b). A study of the effects of a partial retirement scheme at an American university (Allen 2004; Allen et al. 2003) also showed that the proportion opting for early retirement increased after the introduction of the scheme, even though the proportion that chose full-time retirement was lower than the proportion that chose partial retirement. The researchers also investigated the characteristics of those who chose partial retirement in contrast to those who opted for full-time retirement or full-time work and found that the partial retirees had most in common with those who continued to work full-time.

To investigate the assumed effect of instruments such as bonuses and higher wages, we can look at research on the impact of pension levels. This research shows that the pension level (degree of compensation) and financial incentives have an effect on the timing of retirement (Bratsberg et al. 2008; Hernæs et al. 2002). One may therefore expect that an increase in the wage level relative to the pension level would help delay retirement. On the other hand, studies show that fairly substantial additions or deductions are needed to produce an effect on retirement behavior (Hernæs et al. 2000; Krueger \& Pischke 1992). When asked directly, a minority report that they would delay their retirement as a consequence of higher pay (Pedersen 1997). Moreover, a study of retirement preferences after the pension reform among Norwegian private sector employees in 2010 indicates that even though many employees wish to work until a higher age, only a few wish to work full-time (Midtsundstad \& Hyggen 2011). In other words, it remains uncertain whether the supply of labor will increase as a consequence of the incentives embedded in the pension reform.

There are nevertheless major differences between changes in the level of compensation paid as a consequence of amendments to national pension and benefit schemes on the one hand and supplementary compensation that is paid locally at the workplace on the other. For example, it is conceivable that being given priority by the job collective and the employers and receiving extra pay or a bonus locally will have some additional effects beyond the purely financial ones. This could, for instance, provide a sense of being appreciated. In qualitative interviews undertaken in enterprises that have introduced such schemes, this is a factor often referred to by the seniors themselves (see, e.g., Becken 2011; Hilsen \& Salomon 2010; Midtsundstad \& Bogen 2011b). 
The review shows that few policies and facilitation programs for seniors have been evaluated, and that the correlation between the supply of labor by seniors and facilitation for seniors, such as bonuses, subsidized reductions in working hours, and adaptation of job content, is far from unambiguous. The effect of the interventions also appears to vary across industries, organizational forms, and types of labor (Midtsundstad \& Bogen 2011b). For the latter reason, we will control for industry, educational level, type of work, and hours worked in the following analyses, since the type of work performed in the various industries will vary greatly. We will also control for some of the pull and jump factors that earlier research has shown influence the retirement decision, like income and marital status.

\section{Data, method, and model}

The sample used when analyzing the likelihood of disability comprises all individuals turning 60 during the years 2001-2005, who were employed in any of the 713 establishments that participated in a 2005 survey $(N=1758)$ (Gravem \& Villund 2007). When analyzing early retirement (AFP), the sample comprises all individuals working in the same 713 establishments and who turned 61 during the years 2001-2006 (N=4018). Data on individual characteristics, work, and retirement behavior have been drawn from Statistics Norway's (SSB) registries, whereas establishment data, including data on the presence of measures targeting older workers, originate in the above-mentioned enterprise survey conducted in 2005.

The prevalence of IW initiatives and active policies for older workers in the participating enterprises included special measures to retain employees who were 62 or over, most commonly in the form of facilitation of the workplace, options for reduced working hours without pay cuts, and bonuses for those who continued working after the age of 62 (Midtsundstad 2007).

Since we are concerned with measuring the effects of policies for seniors, we need to measure changes in the individual likelihood of retiring on the AFP scheme or with disability benefits before and after the introduction of such policies. We are therefore using a so-called difference-in-differences approach, where we measure the change in the average likelihood of retirement over time between individuals with and without access to interventions for seniors. This is the best available method for measuring actual effects of interventions and regulatory changes (Angrist \& Pischke 2009; Wooldridge 2006). The method presumes that one undertakes a natural experiment or an approximate natural experiment, in which two comparable groups have been subjected to two different schemes during the period of study (here: policies versus no policy). However, we only have data to tell us whether the enterprises have or do not have the policies in question during 2005, and we have no information on the year of their introduction in the individual enterprise. A representative study from 2010 (Midtsundstad \& Bogen 2011b) shows, however, that nearly all the enterprises had introduced such policies for seniors after 2004. We therefore assume that few, if any, of the enterprises in our sample enacted such policies in the period from 2001 to 2004. On the basis of this assumption, we compare the likelihood of retiring on the AFP scheme or because of disability at age 62 prior to and after the introduction of special policies for seniors. 
The method also presumes that the samples are drawn randomly, giving equal likelihood of inclusion in the intervention group and the control group (Angrist \& Pischke 2009). However, the group of Norwegian enterprises that have special policies for seniors is self-selected. Nevertheless, the distribution of older employees in the intervention group and the control group, respectively, of our sample can be assumed to be random, since individual employees have no effect on the introduction of such policies in their own enterprise. In addition, very few employees over 60 years of age actively seek out enterprises with such policies for seniors, since only very few change jobs after the age of 60 .

The purpose of the analyses is to investigate whether working in an enterprise that has policies for older workers effects the likelihood of retiring on the AFP scheme or because of disability. That an enterprise has such policies means that the HR manager/ executive director of the enterprise in November-December of 2005 reported to have enacted one or more policies for the 62-year-olds with the purpose of encouraging them to keep working. A total of $55 \%$ of the municipal employees and $76 \%$ of the central government employees worked in enterprises that had enacted such policies in 2005, but only $30 \%$ of the employees in the private sector did so. The most common policies included extra pay or bonuses after a minimum of one extra year spent working, subsidized reductions in working hours, extra days off, and/or adaptation of the job content (Midtsundstad 2007).

In the analyses, we compare the individual likelihood of a 61-year-old retiring on the AFP scheme at age 62 in 2002, 2003, and 2004, respectively, when no enterprises had enacted such policies, with the likelihood of a 61-year-old retiring on the AFP scheme at age 62 in 2005, 2006, or 2007, respectively, when a known selection of the enterprises had introduced such policies. The reason why we have chosen to investigate only the likelihood of retiring on the AFP scheme at age 62 is associated with the problems of selection bias and the fact that the effect of the policies can be assumed to be at its greatest during the first year of entitlement to an AFP pension. Similarly, we compare the individual likelihood of an employed 60-year-old retiring because of disability some time during the year they turn 62 in a period when few or no enterprises had enacted special policies for seniors, with a period during which a known proportion of the enterprises had introduced such policies. Our argument for doing so is that retirement on disability tends to be a process during which only very few move from employment to disability pension within one and the same year.

The analyses control for the following individual characteristics: gender ('male' is the reference category), level of education divided into primary/lower secondary (ref.), ${ }^{2}$ upper secondary, short and long university or university college education; net income (after tax) divided into percentiles; marital status, i.e., living in a one-person household (unmarried or widow/widower) or married/cohabiting and contractual working hours, i.e., full-time (ref.), long part-time (from 50 to $80 \%$ full-time equivalent), and short parttime (less than $50 \%$ full-time equivalent).

Furthermore, we control for the following characteristics of the enterprises: main profession in the enterprise, ${ }^{3}$ where we distinguish between workers (ref.), lower managers (routine non-manual employees), and upper managers (professionals, administrators, and officials); Public administration (ref.), teaching, health and social services, industry, construction, Hotels and restaurants, wholesale and real estate and other industries; enterprise size, i.e., whether the enterprise has 100 or more employees or not; whether the 
enterprise has an HR manager, no (ref.) or yes; whether the enterprise has undertaken any downsizing during the previous year or the first year in each period studied; and whether the enterprise is an IW enterprise or not, i.e., whether the enterprise joined the IW agreement in 2001, joined the agreement during the period from 2002 to 2005, or have not joined the agreement (ref.). ${ }^{4}$

In Table 1, we show how the sample of older employees is distributed by the various independent variables in the intervention enterprises and the control enterprises, respectively.

Table I Distribution of the independent variables, respectively, in the intervention group and the control group.

\begin{tabular}{|c|c|c|c|c|c|c|c|c|}
\hline & \multicolumn{2}{|c|}{ Measures } & \multicolumn{2}{|c|}{ No measures } & \multicolumn{2}{|c|}{ Measures } & \multicolumn{2}{|c|}{ No measures } \\
\hline & $\begin{array}{c}\text { Disability } \\
\text { analysis }\end{array}$ & $\begin{array}{c}\text { Early } \\
\text { retirement } \\
\text { analysis }\end{array}$ & $\begin{array}{c}\text { Disability } \\
\text { analysis }\end{array}$ & $\begin{array}{l}\text { Early } \\
\text { retirement } \\
\text { analysis }\end{array}$ & $\begin{array}{c}\text { Disability } \\
\text { analysis }\end{array}$ & $\begin{array}{l}\text { Early } \\
\text { retirement } \\
\text { analysis }\end{array}$ & $\begin{array}{c}\text { Disability } \\
\text { analysis }\end{array}$ & $\begin{array}{c}\text { Early } \\
\text { retirement } \\
\text { analysis }\end{array}$ \\
\hline Year & $\begin{array}{l}2001 / \\
2002\end{array}$ & $\begin{array}{l}2001 / \\
2002 / \\
2003\end{array}$ & $\begin{array}{l}2001 / \\
2002\end{array}$ & $\begin{array}{l}2001 / \\
2002 / \\
2003\end{array}$ & $\begin{array}{l}2004 / \\
2005\end{array}$ & $\begin{array}{l}2004 / \\
2005 / \\
2006\end{array}$ & $\begin{array}{l}2004 / \\
2005\end{array}$ & $\begin{array}{l}2004 / \\
2005 / \\
2006\end{array}$ \\
\hline Age & 60 & 61 & 60 & 61 & 60 & 61 & 60 & 61 \\
\hline Women & 49.7 & 44.4 & 50.0 & 40.7 & 36.6 & 43.3 & 36.4 & 45.2 \\
\hline $\begin{array}{l}\text { Elementary } \\
\text { school }\end{array}$ & 18.3 & 18.8 & 21.9 & 21.2 & 18.1 & 13.3 & 17.8 & 17.4 \\
\hline $\begin{array}{l}\text { Secondary } \\
\text { school }\end{array}$ & 47.7 & 48.9 & 45.1 & 44.8 & 47.0 & 51.3 & 50.7 & 49.1 \\
\hline $\begin{array}{l}\text { Lower } \\
\text { degree } \\
\text { university/ } \\
\text { college }\end{array}$ & 26.3 & 23.7 & 24.3 & 23.4 & 21.5 & 22.5 & 22.9 & 23.5 \\
\hline $\begin{array}{l}\text { Higher } \\
\text { degree } \\
\text { university/ } \\
\text { college }\end{array}$ & 7.7 & 8.6 & 8.7 & 10.6 & 13.4 & 12.9 & 8.6 & 10.0 \\
\hline Living alone & 11.7 & 8.1 & 9.8 & 6.0 & 19.3 & 17.0 & 17.9 & 16.8 \\
\hline $\begin{array}{l}\text { Income } \\
\text { percentile, } \\
\text { mean (s.d.) }\end{array}$ & $\begin{array}{c}43.3 \\
(28.5)\end{array}$ & $\begin{array}{c}46.3 \\
(28.6)\end{array}$ & $\begin{array}{c}49.6 \\
(27.8)\end{array}$ & $\begin{array}{c}49.9 \\
(28.2)\end{array}$ & $\begin{array}{c}46.0 \\
(28.9)\end{array}$ & $\begin{array}{c}49.5 \\
(27.3)\end{array}$ & $\begin{array}{c}46.0 \\
(28.2)\end{array}$ & $\begin{array}{c}50.1 \\
(28.2)\end{array}$ \\
\hline $\begin{array}{l}\text { Part-time } \\
<20 \text { hours }\end{array}$ & 12.7 & 8.5 & 15.3 & 7.2 & 11.4 & 4.2 & 12.6 & 7.8 \\
\hline $\begin{array}{l}\text { Part-time } \\
20-29 \text { hours }\end{array}$ & 17.0 & 12.7 & 7.0 & 9.0 & 7.9 & 7.6 & 9.8 & 8.4 \\
\hline
\end{tabular}




\begin{tabular}{|c|c|c|c|c|c|c|c|c|}
\hline $\begin{array}{l}\text { Full-time, } \\
30 \text { hours or } \\
\text { more }\end{array}$ & 70.3 & 78.8 & 77.7 & 83.8 & 80.7 & 88.2 & 77.6 & 83.8 \\
\hline $\begin{array}{l}100 \text { or more } \\
\text { employees }\end{array}$ & 80.0 & 75.0 & 65.0 & 68.2 & 78.7 & 79.5 & 71.1 & 70.0 \\
\hline $\begin{array}{l}\text { Personnel } \\
\text { manager }\end{array}$ & 74.3 & 74.1 & 71.6 & 70.1 & 75.7 & 79.5 & 74.1 & 74.4 \\
\hline $\begin{array}{l}\text { Layoffs this } \\
\text { or last year }\end{array}$ & 7.0 & 8.3 & 6.9 & 7.8 & 11.4 & 42.5 & 22.4 & 27.5 \\
\hline Workers & 32.7 & 32.0 & 47.2 & 46.4 & 36.1 & 29.4 & 48.8 & 47.9 \\
\hline $\begin{array}{l}\text { Routine } \\
\text { non-manual } \\
\text { employees }\end{array}$ & 37.0 & 37.3 & 30.1 & 30.8 & 32.7 & 34.6 & 29.6 & 30.4 \\
\hline $\begin{array}{l}\text { Professionals, } \\
\text { administra- } \\
\text { tors, and } \\
\text { officials }\end{array}$ & 30.0 & 30.5 & 22.0 & 22.2 & 30.2 & 35.5 & 20.3 & 20.7 \\
\hline $\begin{array}{l}\text { Public ad- } \\
\text { ministration }\end{array}$ & 26.7 & 25.7 & 9.8 & 10.5 & 24.3 & 27.5 & 11.5 & 12.3 \\
\hline Teaching & 6.3 & 6.1 & 24.2 & 22.9 & 7.9 & 6.5 & 21.6 & 22.6 \\
\hline $\begin{array}{l}\text { Health } \\
\text { and social } \\
\text { services }\end{array}$ & 22.0 & 18.3 & 12.2 & 9.6 & 18.8 & 17.6 & 11.5 & 8.5 \\
\hline Industry & 5.7 & 5.9 & 13.5 & 14.3 & 9.4 & 8.3 & 8.3 & 10.5 \\
\hline Construction & 3.3 & 3.5 & 13.1 & 14.5 & 4.5 & 5.9 & 15.5 & 12.7 \\
\hline $\begin{array}{l}\text { Hotels and } \\
\text { restaurants }\end{array}$ & 5.3 & 4.9 & 11.3 & 10.5 & 3.0 & 1.7 & 9.5 & 8.4 \\
\hline $\begin{array}{l}\text { Wholesale } \\
\text { and retail } \\
\text { trade }\end{array}$ & 7.7 & 9.9 & 7.7 & 9.4 & 6.9 & 9.9 & 9.1 & 8.9 \\
\hline $\begin{array}{l}\text { Other } \\
\text { industries }\end{array}$ & 23.0 & 25.7 & 8.3 & 9.3 & 25.3 & 22.6 & 13.1 & 16.0 \\
\hline $\begin{array}{l}\text { Non } \\
\text { IW-business }\end{array}$ & 15.0 & 21.4 & 20.2 & 21.2 & 19.8 & 20.0 & 17.6 & 16.6 \\
\hline IW 200 I & 19.7 & 17.1 & 12.2 & 9.8 & 11.9 & 13.8 & 12.8 & 12.6 \\
\hline $\begin{array}{l}\text { IW } \\
2002-2005\end{array}$ & 65.3 & 61.5 & 67.6 & 69.0 & 68.3 & 66.2 & 69.6 & 70.8 \\
\hline$N$ & 300 & 509 & 654 & 1089 & 202 & 659 & 602 & 1765 \\
\hline
\end{tabular}


As can be seen from Table 1, the employees in the intervention group and the control group are relatively similar in terms of gender, marital status, educational level, and average income. However, the intervention group has a slightly higher proportion of employees working part-time, most likely because the intervention group has a higher number of public sector enterprises, especially in health and social services. Furthermore, a higher proportion of the employees in the intervention group work in large enterprises (100 employees or more) and enterprises that joined the IW agreement as early as 2001 . The major difference, however, is associated with the distribution among industries. The intervention group encompasses a far higher proportion of employees in enterprises dominated by white-collar workers and enterprises in public administration and health and social services, and far fewer who work in enterprises dominated by blue-collar workers and enterprises in education, hotel and catering, manufacturing and construction.

\section{Results}

In the following analysis, we first investigate whether the likelihood of receiving a disability pension or an AFP pension at age 62 has changed more during the period from 2002-2004 to 2005-2007 in enterprises that have enacted special policies for seniors, when compared with enterprises that have not introduced such policies.

As shown in Figure 1, there has been an increase in retirement on the AFP scheme among 62-year-olds during the period we are studying. However, the increase has been slower among 62-year-olds working in the control enterprises than among the 62-yearolds in the interventionl enterprises, contrary to what would be expected if the policies were effective.

Figure I: Percentage of 61 -year-olds who retired early with the contractual pension (AFP) as 62-year-olds in firms with and without measures (2002-2006).

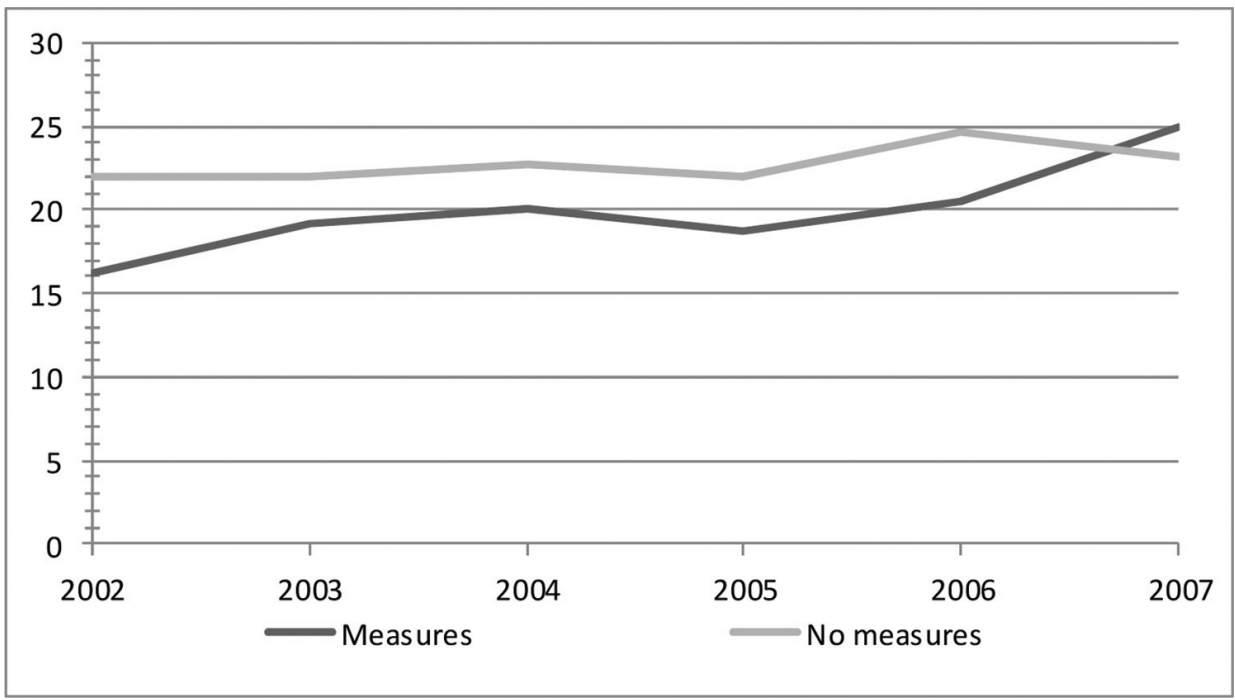


Figure 2: Percentage of 60-year-olds (200I-2004) who were receiving disability benefits as 62-year-olds (2002-2007) in firms with and without measures.

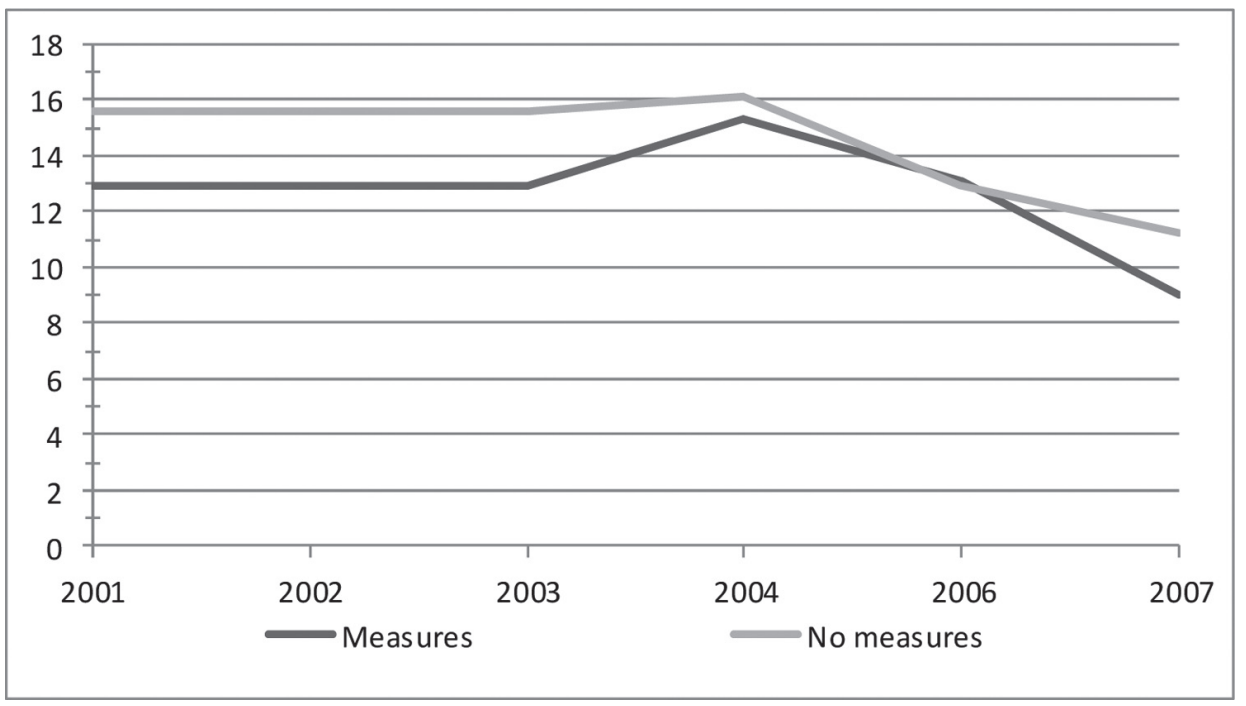

On the other hand, as Figure 2 shows, there has been a decrease in retirement on disability pension in both the intervention enterprises and the control enterprises during the period we are studying, and for those who turned 62 years after 2005 the decrease in retirement has been somewhat stronger in the intervention enterprises than in the control enterprises.

However, in order for our model to measure the true effect of the policies, we need to assume that the groups are comparable over time. This is not very likely, we therefore control for a number of individual and enterprise-level characteristics that have been shown by previous studies to have an impact on the likelihood of early retirement (different pull, push, and jump factors) and, as Table 1 shows, also vary between the intervention enterprises and the control enterprises in our sample.

In the following analysis, we study whether the fact of having or not having measures in order to delay retirement has an impact on the likelihood of receiving disability pension or AFP pension. These differences in average change are also referred to as a difference-in-differences estimator (Angrist \& Pischke 2009; Wooldridge 2006).

Since the dependent variables are binary categorical variables, we have used logistic regression. In Table 2, we report odds ratios with a 95\% confidence interval. All models are also estimated as linear probability models, and these yield substantially identical results (not shown). All analyses were performed using Stata, version 10.1.

First, we investigate the total effect of the policy by including the policy itself, a dummy variable for the year, and the interaction between policy and year (the effect). This gives us an indication of the gross effect of the policy. However, it is highly unlikely that enterprises with policies are identical to those without in all other respects, or that the people working in enterprises with policies are identically similar to those in enterprises without policies, as shown by Table 1 . We have therefore 
Table 2 Individual probability of receiving an early retirement benefit or a disability benefit among 62 -year-olds, depending on the measure exposure, before and after controlling for a range of individual and enterprises' characteristics. $O R=$ odds ratio.

\begin{tabular}{|c|c|c|c|c|}
\hline & $\begin{array}{l}\text { Early retirement } \\
\text { Model I }\end{array}$ & $\begin{array}{l}\text { Early retirement } \\
\text { Model } 2\end{array}$ & $\begin{array}{l}\text { Disability } \\
\text { Model I }\end{array}$ & $\begin{array}{l}\text { Disability } \\
\text { Model } 2 \\
\end{array}$ \\
\hline & OR & OR & OR & OR \\
\hline Women & & 0.925 & & 1.132 \\
\hline Living alone & & $0.669 * * *$ & & 1.357 \\
\hline Elementary school (ref) & & 1.000 & & 1.000 \\
\hline Secondary school & & 0.855 & & 0.771 \\
\hline Lower degree university/college & & 0.877 & & $0.603 * *$ \\
\hline Higher degree university/college & & 0.768 & & $0.447 *$ \\
\hline Income percentile & & $0.99 \mid * * * *$ & & 0.995 \\
\hline Full-time, 30 hours or more (ref) & & 1.000 & & 1.000 \\
\hline Part-time 20-29 hours & & $0.727 * * *$ & & 1.478 \\
\hline Part-time $<20$ hours & & 0.974 & & 12.050***** \\
\hline I00 or more employees & & $1.167 *$ & & $1.362 *$ \\
\hline Personnel manager & & $0.848 *$ & & 0.881 \\
\hline Layoffs this or last year & & 1.253** & & 0.757 \\
\hline Workers (ref) & & 1.000 & & 1.000 \\
\hline Routine non-manual employees & & 1.400**** & & $0.623 * *$ \\
\hline $\begin{array}{l}\text { Professionals, administrators, } \\
\text { and officials }\end{array}$ & & 1.121 & & $0.535 * *$ \\
\hline Public administration (ref) & & 1.000 & & 1.000 \\
\hline Teaching & & $1.514 * *$ & & 1.460 \\
\hline Health and social services & & $0.669 * *$ & & 0.700 \\
\hline Industry & & $2.147 * * * *$ & & 0.787 \\
\hline Construction & & $2.146 * * * *$ & & 1.117 \\
\hline Hotels and restaurants & & 1.563** & & 1.409 \\
\hline Wholesale and retail trade & & 1.835**** & & 1.194 \\
\hline Other industries & & $2.325 * * * *$ & & 0.915 \\
\hline $\begin{array}{l}\text { Non IW business and } \\
\text { IW 2002-2005 (ref) }\end{array}$ & & 1.000 & & 1.000 \\
\hline IW 2001 & & 0.829 & & 1.061 \\
\hline Measures & 0.718 & $0.762 * *$ & 0.745 & 0.848 \\
\hline $\begin{array}{l}\text { Change from first period to } \\
\text { second period }\end{array}$ & 0.937 & 0.956 & $0.598 * * * *$ & $0.56 \mid$ ***⿻丷木大 \\
\hline Measures* change & 1.280 & 1.273 & 0.998 & 1.035 \\
\hline Pseudo $R^{2}$ & 0.002 & 0.037 & 0.012 & 0.197 \\
\hline$N$ & 4018 & 4018 & 1758 & 1758 \\
\hline
\end{tabular}

$*: p<=0.05 ; * *: p \leq 0.01 ; * * * * p \leq 0.001$ 
included a model that allows us to control for various individual and enterprise characteristics.

The analysis shows that the policies for seniors have no significant effect on the likelihood that the 62-year-olds will retire on the AFP scheme, as can be seen in Table 2. This is evident both before and after control for the selected individual and enterpriselevel characteristics.

On the other hand, whether you live alone or not, the net after-tax income level of the 61-year-olds and their contractual working hours have an effect on this individual likelihood. The probability that a 62-year-old will retire on the AFP scheme decreases with increasing income. The probability to retire is also lower for those living alone compared with those not. Older employees who works part-time (20-30 hours a week) also have a significantly lower likelihood of retiring on the AFP scheme at age 62 than other 62-year-olds who work full-time. Furthermore, those working in large enterprises with 100 or more employees compared with those working in smaller enterprises and those working in enterprises which experienced downsizing have a higher probability to retire compared with employees in enterprises with no such experience. Moreover, those not working in public administration and health and social service and those working in enterprises dominated by routine non-manual employees have a higher probability to retire than those working in other industries and enterprises dominated by manual workers. The other control variables have no effect on the likelihood of retiring with an AFP pension.

The analysis of the effect of the policies for seniors with regard to the likelihood of being retired on disability pension at age 62 while having been employed at age 60 , shown in Table 2, shows that providing the policies from age 62 has no significant effect in this respect. This can be observed both before and after control for the relevant individual and enterprise-level characteristics.

However, employees with higher education and employees working full-time have a lower probability to retire on disability pension than employees with elementary education and employees working part-time (less than 20 hours per week). Furthermore, those working in large enterprises with 100 or more employees compared with those working in smaller enterprises and those working in enterprises dominated by white-collar workers and not blue-collar workers have a higher probability to retire. The other control variables have no effect on the likelihood of retiring with a disability pension.

\section{Discussion}

The results of the analyses show that working in an enterprise that provides special policies for seniors to workers from age 62, like bonuses, reduced working hours, and extra days off, does not have an effect on the likelihood of a 61-year-old receiving an AFP pension at age 62 nor on the likelihood of a 60 -year-old retiring on a disability pension two years later, i.e., at age 62 .

In both cases, this is evident both before and after controlling for some of the known individual risk factors such as gender, level of education, level of income, material status, and contractual working hours, as well as after controlling for enterprise characteristics such as the number of employees, the presence of a separate HR manager, layoffs during the period, the main profession in the enterprise, industry, and the time of joining the 
IW agreement. This means that the absence of any effects cannot be ascribed to differences in these respects between individuals working in intervention enterprises and those working in the enterprises that constitute the control group.

One explanation of the absence of any effect could be that we only have information on whether the enterprises have introduced the policies described, but we do not know whether each individual employee has received this option. With regard to the policies for seniors, however, this explanation is not very likely; since we know from other studies (e.g., Midtsundstad 2007, Midtsundstad and Bogen 2011b) that such initiatives are usually open to everybody in the enterprise, from the same age onward. Some are nevertheless excluded, for example, those who have a small full-time equivalent in the health and care sector. In our sample, altogether about $12 \%$ of the 61 -year-olds were working short part-time or had a contractual full-time equivalent of less than $50 \%$.

The fact that the typical policies targeting employees who are 62 or over fail to have an effect may also be due to the fact that those who are entitled to such initiatives are a strongly selected group of people who can be assumed to be more healthy and motivated for work than the cohort as a whole, since a large proportion of employees retire on disability before they turn 60 . In other words, the policies may appear to be less important for the selected group, since they already constitute a relatively healthy and well-motivated group of employees.

The absence of effect may also be associated with the types of policies that the enterprises provide for the majority of their employees from age 62. In most enterprises, the initiatives include various forms of financial incentives such as reduced working hours with full wage compensation or bonuses/increased wages (Midtsundstad \& Bogen $2011 b)$. Several studies also show that a considerable proportion of older employees claim that they would continue working if they were granted bonuses or higher wages or reduced working hours with full wage compensation (Midtsundstad 2006, 2009b; Mykletun et al. 2000). However, for such initiatives to have an effect, more leisure time and money must be the factors that best fit the needs of employees who normally retire at age 62. Previous studies indicate, however, that those who wish to retire at age 62 tend to report health problems and physical and mental strains on the job as the main reasons (Midtsundstad 2006). Therefore, the typical initiatives offered by Norwegian enterprises in 2005 will not necessarily meet the needs of the seniors.

In the analyses, we have had no access to data that would have allowed us to control for factors related to health status, the working environment, and working conditions, which in previous studies have proven to be a significant explanation for why elderly employees take early retirement. It is therefore conceivable that the working conditions and the working environment in enterprises that offer facilitation and/or special initiatives for seniors are on the whole less favorable than in enterprises that do not provide such initiatives, thus providing an explanation for the absence of any effects. This means that the initiatives may have an effect, but this is not sufficient to counterbalance the negative effects of the working environment. We do, however, control for level of education, main type of profession in the enterprise, and industry. This may nevertheless fail to capture all the differences in working conditions between individuals working in the same types of industries.

It also bears mentioning that the intervention enterprises do not constitute a random sample, but are self-selected since the enterprises may independently decide whether or not to join the IW agreement and establish various forms of facilitation and initiatives 
for seniors. This may have an impact on the results, provided that the factors that induce the enterprise to establish policies for seniors also have an impact on the likelihood of employees retiring because of disability or on the AFP scheme, all else being equal. However, we are measuring the changes in the individual likelihood of early retirement, not the changes in the enterprises' rates of early retirement as described in the introduction, and there is a significant likelihood that the distribution of elderly employees between the intervention enterprises and the control enterprises is random, even though the sample of intervention enterprises and control enterprises is not.

Last but not least, an absence of effects could be caused by what we may refer to as a kind of national "Hawthorne effect." This means that the intensified political focus and debate over the last decade with regard to an inclusive labor sphere and the need for a reduction in the rate of early retirement may have influenced all Norwegian enterprises and employees, irrespective of whether the enterprises have chosen to establish policies for seniors or not. This "opinion and attention effect" during the business boom from 2001 to 2007 may thus have been stronger than the effects of the policies as such.

In line with this reasoning, it may also be that the general good economic situation of older workers in Norway and increased average incomes among seniors during the last decade have influenced the retirement decision for most Norwegian seniors and hence weakened the possible influence of the common measures offered, like bonuses and subsidized work time reductions. According to economic theory, increased income increases the preferences for leisure (the income effect), everything else being equal.

\section{Conclusion}

In this article, we investigate whether the enterprises' independently initiated policies for seniors had an effect on the likelihood of elderly employees retiring on a disability pension or on the AFP scheme during the period from 2001 to 2007 . We study whether the individual likelihood of receiving an AFP or a disability pension at the age of 62 has decreased more for employees who are working in enterprises that have enacted special policies for those who are 62 or older than for employees who work in enterprises that have not introduced similar initiatives. We use a "difference-in-differences" approach, whereby the changes in the individual likelihood of retiring on a disability pension and/ or an AFP pension are compared for enterprises that have such policies and those that have none, controlled for a number of individual and enterprise-level characteristics.

The analyses show that the initiatives commonly offered by Norwegian enterprises and often recommended in the international literature, like reduced working hours, extra day off, and economic incentives, fail to produce the expected effects. We can nevertheless observe a reduction in the rate of early retirement on disability pension among the 62-year-olds during the period of study. However, we cannot ascribe this reduction in the probability of receiving a disability pension to commonly offered initiatives for seniors since we are unable to demonstrate statistically that the development of the individual likelihood of retiring on a disability pension has differed for employees working in enterprises that have enacted the policies in question, when compared with those working in enterprises without such initiatives. Even after controlling for exposure to the policies, we find that known risk factors such as level of education, income, material status, and type of enterprise remain decisive. In other words, it appears as though the 
policies followed by Norwegian enterprises in late 2005 have failed to delay or reduce the rate of early retirement.

Special policies for seniors may nevertheless still have an effect. As indicated by previous studies, the lack of effects may be associated with the specific types of initiatives that are provided: for example, with regard to whether they fulfill the needs of the employees in question. Furthermore, the lack of effects may be caused by the terms of the allocation criteria and allocation routines that have been established, for example, whether or to which degree all those who need special facilitation are entitled to it and are familiar with their options, as well as whether those who grant such facilitation have sufficient time and resources to implement the policies, assess individual needs, and follow up each individual employee.

Research has shown that the causes of early retirement are complex and are generated by a number of different factors within as well as outside the workplace. The various factors also have a varying degree of importance for different professions and educational groups. One would therefore assume that in order to be effective, the initiatives and instruments launched to prevent early retirement would need to vary between professions, industries, and sectors. However, they do not in Norway today. The options and the allocation criteria are surprisingly similar across industries and enterprises, despite the heterogeneity of needs, problems, and challenges. This can be observed between as well as within the individual enterprises (Midtsundstad \& Bogen 2011). Emphasis is placed on measures such as reduced working hours with full pay, extra days off and/or bonuses, and only to a lesser extent on facilitation and adaptation of the job situation. The age requirement for eligibility or provision of special measures also appears to be excessive in some industries (62 years). Those groups of workers who are at risk of disability and may have the most pronounced need for facilitation will therefore not invariably be able to benefit from the special policies for older workers. The senior policies operating in the current Norwegian labor market are thus not very accurate and appear to have the character of benefits for older workers who would have continued working anyway rather than of effective measures to reduce the rates of early retirement.

\section{Acknowledgment}

The project was financed by FARVE - forsøksmidler arbeid og velferd (The Norwegian Labour and Welfare Administration).

\section{References}

Allen, S. G. (2004) 'The value of phased retirement', NBER Working Paper 10531.

Allen, Steven G., Clark, R. L. \& Ghent, Linda S. (2003) 'Phasing into retirement.' Industrial and Labor Relations Review, vol. 58 (1): 112-127.

Angrist, A. D. \& Pischke, J.-S. (2009) Mostly Harmless Econometrics. An Empirist's Companion. Princeton: Princeton University Press.

Becken, L.-E. (2011) 'Reduced work hours with full wage compensation among senior workers eligible for AFP in four government agencies'. ['Redusert arbeidstid med full 
lønnskompensasjon blant seniorer med rett til AFP i fire statlige etater'], Søkelys på arbeidslivet, vol. 28(4): 374-393.

Bowitz, E. (2003) Older workers' exit from the labor force. [Eldres avgang fra arbeidsstyrken]. Forskningsrapport 2003-104. Oslo: Econ analyse.

Bratsberg, B., Røed, K. \& Raaum, O. (2008) 'Does work have to pay in an including worklife?’ ['Må arbeid lønne seg i et inkluderende arbeidsliv?'], Tidsskrift for Velferdsforskning, vol. 11(1): 49-61.

Delsen, L. \& Reday-Mulvey, G. (eds.) (1996) Gradual Retirement in the OECD Countries. Aldershot: Dartmouth.

De Luna, X., Stenberg, A. \& Westerlund, O. (2008) Can adult education delay retirement from the labour market? Working paper 6/2008, Stockholm: Swedish Institute for Social Research (SOFI).

Gravem, D. \& Villund, O. R. (2007) Survey on senior policy in Norwegian establishments, phase 1. Dokumentation report. [Undersøkelse om seniorpolitikk i norske virksombeter, fase 1. Dokumentasjonsrapport]. SN-report 2007/44. Oslo: Statistic Norway.

Haga, O. (2010) Expected retirement age 1986-2009. ['Forventa pensjoneringsalder 1986-2009’]. Arbeid og velferd nr. 2/2010, Oslo: Arbeids og velferdsdirektoratet.

Hallberg, D. (2007) Older workers work opportunities and employment possibilities. A literature review [Äldres arbetsutbud och möjligheter till sysselsättning, enkunskapsöversikt], DS 2007: 21, Min. of Finance, Sweden.

Hauge, L. \& Årethun, T. (2008) Who retires on AFP? [Kven går av med AFP?]. NAV-rapport nr. 3. Oslo: Seksjon for statistikk og utredning, Arbeids- og velferdsdirektoratet.

Hernæs, E., Røed, K. \& Strøm, S. (2002) Employment, retirement and economic incentives. [Yrkesdeltakelse, pensjoneringsatferd og økonomiske insentiver.] Rapport 4/2002. Oslo: Stiftelsen Frischsenteret for samfunnsøkonomisk forskning.

Hernæs, E., Sollie, M. \& Strøm, S. (2000) 'Early retirement and economic incentives', Scandinavian Journal of Economics, Vol. 102(3): 481-502.

Hilsen, A. I. \& Salomon, R. (2010) Senior policy - does measures work? [Seniorpolitikk virker virkemidlene?], AFI-rapport 4/2010. Oslo: Arbeidsforskningsinstitiuttet.

Hilsen, A. I. \& Steinum, T. (2006) Tell me I am needed! [Fortell meg at jeg er ønsket! Sluttrapport fra Livsfaseprosjektet i trygdeetaten, et prosjekt under Nasjonalt krafttak for seniorpolitikk $i$ arbeidslivet.] Rapport nr. 2/2006. Oslo: Arbeidsforskningsinstituttet.

Hurd, M. D. \& McGarry, K. (1993) The relation between job characteristic and retirement. National Bureau of Economic Research, Working Paper, no. 4558.

Ilmarinen, J. (2003) 'Promotion of work ability during ageing'. In Kumashiro, M. (ed.) Ageing and Work. London: Taylor \& Francis, 2003: 23-35.

Ilmarinen, J. \& Louhevaara, V. (eds.) (1999) FinnAge - respect for the ageing: action programme to promote health, work ability and well-being of ageing workers in 1990-96. People and work - research reports 26. Helsinki: Finnish Institute of Occupational Health.

Jepsen, M., Foden, D. \& Hutsebaut, M. (eds.) (2003) A Lifelong Strategy for Active Ageing. Brussels: European Trade Union Institute (ETUI).

Jørgensen, M. S., Larsen, M. \& Rosenstock, M. (2005) A longer work life. Retirement schemes and work place opportunities [Et lengre arbejdsliv. Tilbagetrekningsordninger og arbejdspladsens muligheder]. Rapport 05: 03. København: SFI- Det nationale forskningscenter for velfærd.

Kandolin (1999) 'Using the experience of ageing persons to improve the planning of shift schedules of health care workers'. In Ilmarinen, J. \& Louhevaara, V. (eds.) FinnAge-Respect for the Ageing: Action Programme to Promote Health, Work Ability and Well-Being of Ageing Workers in 1990-96. People and work-research reports 26. Helsinki: Finnish Institute of Occupational Health. 
Krueger, A. \& Pischke, J.-S. (1992) 'The effect of social security on labour supply: A cohort analysis of the notch generation'. Journal of Labour Economics, vol. 10(4): 412-437.

Larsen, M. (2005) Retaining Older Workers in the Danish Labour Market. Phd thesis. Department of Economics. Aarhus: Aarhus School of Business.

Leiulfsrud, H., Bison, I. \& Jensberg, H. (2005) Social Class in Europe. European Social Survey 2002/3. Trondheim: NTNU.

Lindquist, G. S. \& Wadensjö, E. (2009) The labor market for older workers [Arbetsmarknaden för de äldre]. Studier i fianspolitik 2009/7. Stockholm: Finnspolitiska rådet.

Mayhew, K. \& Rijkers, B. (2004) 'How to improve the human capital of older workers or the sad tale of the magic bullet', paper prepared for the joint EC-OECD Seminar on Human Capital and Labour Market Performance, Brussels, Dec 8, 2004.

Midtsundstad, T. (2002) AFP-retiree: tired - or healthy and able-bodied? [AFP-pensjonisten: Sliten - eller frisk og arbeidsfør? Analyse av fortidspensjonering og bruk av AFP i LONHO-området]. Fafo-rapport 385. Oslo: Fafo.

Midtsundstad, T. (2005a) 'Not necessarily tired... An analysis of public sector AFP retirement.' ['Ikke nødvendigvis sliten... En analyse av AFP-pensjonering i staten.'], Søkelys på arbeidsmarkedet, vol. 22(2): 217-232.

Midtsundstad, T. (2005b) Not necessarily tired... An analysis of early retirement and senior policy in public sector. [Ikke nødvendigvis sliten... En analyse av tidligpensionering og seniorpolitikk $i$ staten]. Fafo-rapport 482. Oslo: Fafo.

Midtsundstad, T. (2006) How to prolong a career - a review of Norwegian and international research on early retirement and senior policy. [Hvordan bidra til lengre yrkeskarrierer? En oversikt over norsk og internasjonal forskning om tidlig pensjonering og seniorpolitikk.] Fafo-rapport 534. Oslo: Fafo.

Midtsundstad, T. (2007) 'Does the labor market want older workers? A review of Norwegian enterprises' commitment to senior workers'. ['Vil arbeidslivet ha seniorene? En oversikt over norske virksomheters seniorengasjement'], Søkelys på arbeidslivet, vol. 24(1): 95-111.

Midtsundstad, T. (2009) Better health, less toil and more family [Bedre helse, mindre slit og mer familie. Delrapport 6 Liv og arbeid - mulighetenes arbeidsliv for alle? Et prosjekt om forutsetningene for et bedre og lengre yrkesliv]. Fafo-rapport 2009: 16. Oslo: Fafo.

Midtsundstad, T. \& Bogen, H. (2011a) ‘Senior politics - a need for adjustments?' ['Seniorpolitikk - behov for justering? Analyse av praksis i seks foregangskommuner'] Søkelys på arbeidslivet, vol. 28(1-2): 89-106.

Midtsundstad, T. \& Bogen, H. (2011b) Different work - different needs. Senior policy in Norway. [Ulikt arbeid - ulike behov. Seniorpolitisk praksis i norsk arbeidsliv]. Faforapport 2011: 10. Oslo: Fafo.

Midtsundstad, T. \& Hyggen, C. (2011) Pensions at the stock exchange - choises and risks. [Pensjoner på børs - valg og risiko]. Fafo-notat 2011: 05. Oslo: Fafo.

Midtsundstad, T., Nielsen, R. \& Hermansen, Å. (2012) 'Work adaptations and senior measures - do they influence municipal sickness leave and early retirement?' ['Tilrettelegging og seniortiltak - påvirker det kommuneansattes sykefravær og tidligpensjonering'], Søkelys på arbeidslivet. vol. 29(1-2): 130-150.

Mykletun, A., Mykletun, R. J. \& Solem, P. E. (2000) Attitudes towards age and work in municipalities. Possibilities to reduce early exit Holdninger til alder og arbeid $i$ kommunesektoren. [Muligheter for å motvirke tidlig yrkesavgang.] KLP-rapport 2000. Oslo: KLP forsikring.

NOU Norges Offentlige Utredninger (2010) Work for health. Sickness leave and exclusion in health and social services. [Arbeid for helse. Sykefravor og utstøting $i$ helse- og omsorgssektoren]. Oslo: Sosial- og omsorgsdepartementet.

OECD (2006) Live Longer, Work Longer. Ageing and Employment Policies. Paris: OECD. 
Olberg, D. (2006) 6 hours work day trial - regimes and experiences [Forsøk med 6-timersdag - ordninger og erfaringer]. Fafo-notat 2006: 23. Oslo: Fafo.

Panis, C., Hurd, M., Loughran, D., Zissimopoulos, J., Haider, S. \& St Clair, P. (2002) The Effect of Changing Social Security Administration's Early Entitlement Age and the Normal retirement Age. Santa Monica: RAND.

Parkatti, T., Kinnunen, U. \& Rasku, A. (1999) 'Work, well-being and health among ageing teachers'. In Ilmarinen, J. and Louhevaara, V. (eds.) FinnAge-Respect for the Ageing: Action Programme to Promote Health, Work Ability and Well-Being of Ageing Workers in 1990-96. People and work-research reports 26. Helsinki: Finnish Institute of Occupational Health.

Pedersen, A. W. (1997) Between work and retirement. [Mellom arbeid og pensjon. Rapport fra en spørreundersøkelse]. Fafo-rapport 223. Oslo: Fafo.

Philipson, C. \& Smith, A. (2005) Extending working life: A review of the research literature. Research Report No. 299. Leeds: Department for Work and Pension.

Pohjonen, T. (2001) 'Perceived work ability of home care workers in relation to individual and work-related in different age groups'. Occupational Medicine, vol. 51(3): 209-217.

Ryan, P., Garonna, P. \& Edwards, R. (eds.) (1991) The Problem of Youth: The Regulation of Youth Employment and Training in Advanced Economies. London: Macmillan.

Solem, P. E. (2001) To old? A review on ageing, work and retirement. [For gammel? Kunnskapsstatus om aldring, arbeid og pensjonering.] NOVA rapport 4/01. Oslo: Norsk institutt for forskning om oppvekst, velferd og aldring.

Steinum, T., Hilsen, A. I. \& Bull, H. (2007) A review of the FARVE-program (research funding on work and welfare) [Kunnskapsstatus for programmet FARVE (forsøksmidler arbeid og velferd). Tema: A øke den giennomsnittlige avgangsalderen.] AFI-notat 10/2007. Oslo: AFI.

Sterdyniak, H. (2007) Finland 2007. Active Ageing Strategies to Strengthen Social Inclusion. Synthesis Report. On behalf of the European Commission, DG Employment, Social AFFAIRS and Equal Opportunities. www.peer-review-social-inclusion.eu. Paris: OFCE.

Stortingsmelding nr. 6 (2006-2007) On senior policy. Seniors - an important resource in the Norwegian labor market. [Om seniorpolitikk. Seniorene - en viktig ressurs i norsk arbeidsliv] White paper. Oslo: Ministry of Labor.

Taylor, P. (2006) Employment initiatives for an ageing workforce in the EU15. Dublin: European Foundation for the Improvement of Living and Working Conditions.

Torgén, M., Stenlund, C., Ahlberg, G. \& Marklund, S. (2001) Ett hållbart arbetsliv för alle aldrar. Stockholm: Arbetslivsinstitutet.

Vickerstaff, S., Loretto, W. \& Whith, P. (2009) 'The future of older workers: opportunities and constraints'. In Loretto, W., Vickerstaff, S. \& White, P.J. (eds.) The Future of Older Workers. Bristol: Policy Press, 2009: 203-226.

Visser, J. (2002) 'The first part-time economy in the world: a model to be followed?' Journal of European Social Policy, vol. 12(1): 23-42.

Wadensjö, E. (2006) Part-Time Pensions and Part-Time Work in Sweden. Discussion paper No. 2273, August 2006, Bonn: Forchungsinstitut fur Zukunft der Arbeit (IZA).

Walker, A. (1999) Managing an ageing workforce: A guide to good practice. Dublin: European Foundation for the Improvement of Living and Working Conditions.

Walker, A. (1997) Combating age barriers in employment. European Research Report. Luxembourg: Office for Official Publications of the European Communities.

Wooldridge, J. (2006) Introductory Econometrics: A Modern Approach. Mason, OH: Thomson/South-Western. 


\section{End notes}

${ }^{1}$ In other words, a possible selection bias has not been taken into account. By interviewing only those who have continued working, a large number of those who have taken this option to retire at age 62-65 years have been left out. In addition, other research tells us that there can be a major difference between the time someone reports to wish to retire and the reasons for doing so (retirement preferences) on the one hand, and the time of actual retirement and reasons for doing so on the other (retirement behavior).

${ }^{2}$ Including those with unknown education and those with education not stated.

${ }^{3}$ Classifying the different occupations, we have used Erikson Goldthorpe coding based on the International Standard Classification of Occupations (ISCO88) (Leiulfsrud et al. 2005). However, we have classified nurses as workers, and not as non-manual employees, since nurses' work to a large extent is manual and physical rather than purely administrative. In addition, previous studies imply that this might influence sickness absence and early retirement behavior (cf. e.g. Midtsundstad and Bogen 2011b).

${ }^{4}$ IW enterprises have access to some public services that are unavailable to others. This includes a designated contact person in the Norwegian Labour and Welfare Administration (NLWA), and previously they could also use active sick leave without prior approval from NLWA (the scheme has since been discontinued). In addition, the employees have an expanded entitlement to use self-reporting of absence due to illness (maximum 24 days per year, as opposed to 12 for others). Furthermore, the enterprise health services in IW enterprises use a separate set of rates for refunds by the National Insurance Service. 